Proceedings of the 2018 International Scientific Conference 'Economic Sciences for Agribusiness and Rural Economy' No 1, Warsaw, 7-8 June 2018, pp. 188-193

ISBN 978-83-7583-802-2

DOI: $10.22630 /$ ESARE.2018.1.26

\title{
CHANGES OF BANKRUPTCY PROCEEDINGS: IMPLICATIONS FOR AGRIBUSINESS SECTOR
}

\author{
Katarzyna Boratyńska, $\mathrm{PhD}^{1}$ \\ Faculty of Economic Sciences, Warsaw University of Life Sciences - SGGW
}

\begin{abstract}
Corporate bankruptcy generates the externalities that affect also agribusiness and local communities. Economies around the world have undertaken reforms aimed at improving their insolvency systems. The majority of the countries including Poland focused on introducing or strengthening reorganization mechanisms. The aim of this study was to present the changes of bankruptcy proceedings that support agribusiness entities survival from economic perspective. This study indicates also the role and support of the State in the restructuring proceedings creation. This is a conceptual article. The methods include comparative and descriptive analysis. As a result, restructuring proceedings provide an opportunity for a debtor to avoid declaration of bankruptcy through enabling him return to going concern status.
\end{abstract}

Keywords: bankruptcy, restructuring proceedings, agribusiness sector JEL codes: G33, Q13, Q14

\section{INTRODUCTION}

The properties of agribusiness can either catalyse or inhibit liquidation of the businesses. Agribusiness characteristics - unique for this subset of the economy - determine not only their specificity, but also the propensity of economic entities to develop and fail in this environment. Over the past three decades, liquidation, discontinuance, and bankruptcy studies have presented approaches to describe business failure and its consequences (Evans and Borders, 2014; Amankwah-Amoah, 2016). FrancDąbrowska, Porada-Rochoń, Suwała, (2016) examine the issue of enterprise insolvency and the effect it has on local and regional communities. The study by Franc-Dąbrowska, Porada-Rochoń, Suwała (2016) included the following stages: a survey of the relevant literature, the development of two panel models, the opportunities and the risks factors determining solvency problems of SMEs on the local and regional community. The research material was balanced and structured as a panel about microdata on financial-economic considerations. The micropanel includes aggregate information on an annual basis for the years 2007-2011 for 215 SMEs, giving a total of 1,075 . The analysis of cross-sectional data uses a linear regression model for panel data with random effects. The companies being researched are divided into two groups: Model 1 for enterprises that present the level of current liabilities below the median level of current liabilities for the whole sample, Model 2 for enterprises that present the level of current liabilities higher than the median level of current liabilities for the whole sample. Two types

${ }^{1}$ Corresponding author: Nowoursynowska 166,02-787 Warsaw, Poland, katarzyna_boratynska@sggw.pl, +4822 5934275 
of estimation are applied: fixed effects and random effects (Franc-Dąbrowska, Porada-Rochoń and Suwała, 2016).

Due to the first symptoms of insolvency, such as difficulty or an inability to settle liabilities when they come due, a model was adopted for the dependent variable level of commitments. It was found that companies with excessive level of commitments are more exposed to the risk of insolvency. The research enabled the identification of determinants for forming commitments. It is very important that the inability of just one company to meet its obligations can have significant consequences for the local market (Franc-Dąbrowska, Porada-Rochoń and Suwała, 2016).

The study by Boratyńska (2016) focused on implementing fuzzy set Qualitative Comparative Analysis (fsQCA) and asymmetric thinking to corporate bankruptcy evaluation in the food industry. It examined the main reasons for corporate bankruptcy, namely, lack of financial liquidity, exceptionally high level of liabilities, losses, weak management, and late recovery actions.
Economies around the world have undertaken reforms aimed at improving their insolvency systems. The majority of them concentrated on introducing or strengthening restructuring mechanisms. Empirical evidence on how these reforms affect the chances of agricultural businesses restructuring is limited, thus the topic deserves for an investigation.

\section{THEORETICAL FRAMEWORK}

The study presents conceptual framework in the area of restructuring and bankruptcy reforms that are the most efficient for business survival. Figure 1 presents the concept of key elements implications of restructuring reforms for agribusiness practice. Considering, early warning systems are one of key factors of a successful agribusiness entities restructuring. Bankruptcy generates public and private costs, making it extremely important to avoid this negative phenomenon in agribusiness practice. The implementation of early warning system for bankruptcy prediction could help restructuring in advance.

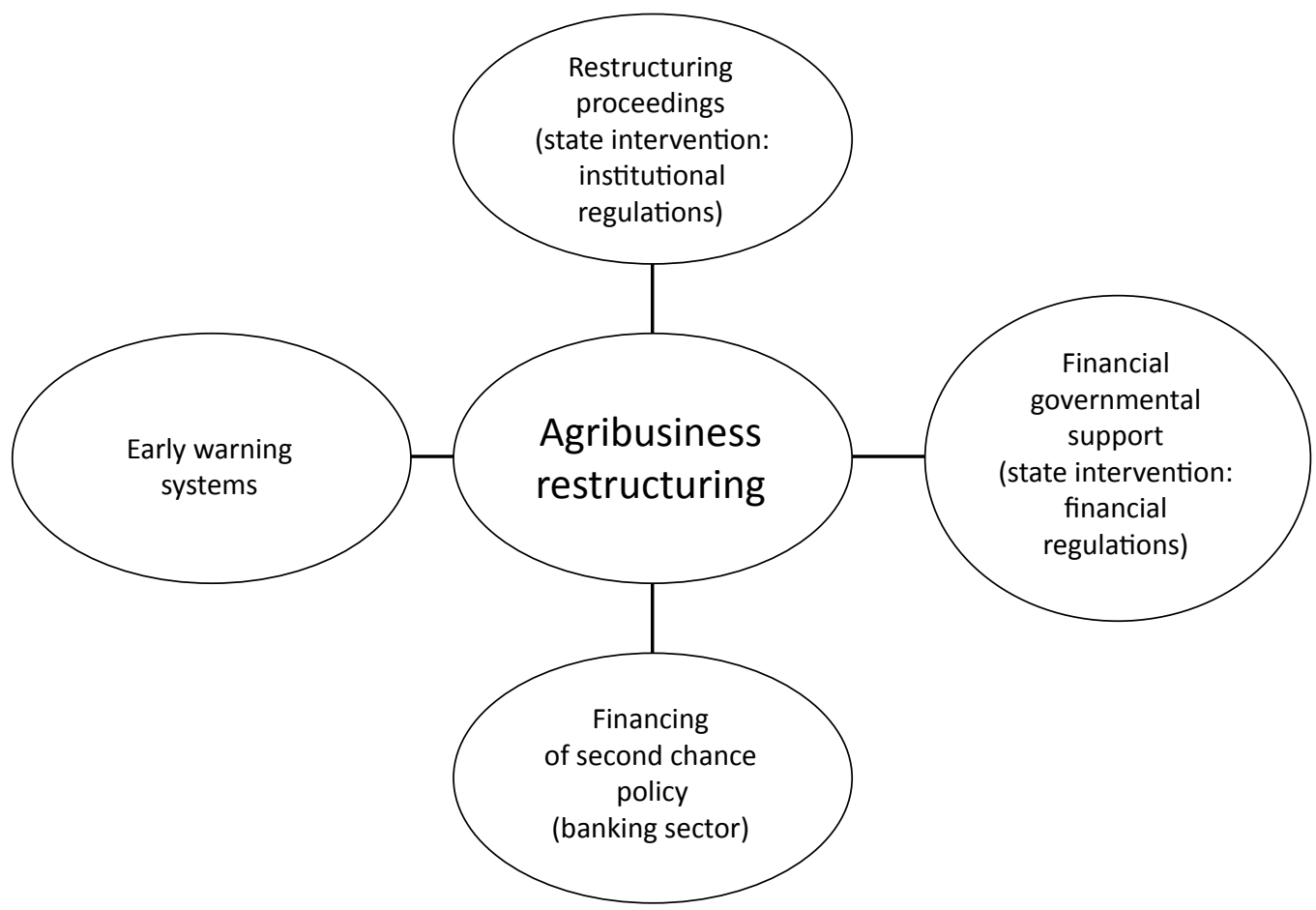

Figure 1. Concept of key elements implications of restructuring reforms to agribusiness practice Source: own study. 
This concept emphasizes also the role of the State intervention, namely institutional and financial regulations. On 1 January 2016 the new restructuring law of 15 May 2015 (the so-called Restructuring Law) came into force. It implements a significant reform of Polish insolvency law, comprising: the introduction of new restructuring procedures, allowing the restructuring of a debtor's undertaking and preventing its bankruptcy, and major amendments to the Bankruptcy and Rehabilitation Law of 28 February 2003 (the so-called Bankruptcy Law) in order to streamline 'classic' bankruptcy proceedings, reduce unnecessary formalities and expedite liquidation and to implement substantive changes, such as: implementing procedures facilitating pre-packs (Act of 15 May 2015 Restructuring Law; Act of 28 February 2003 Bankruptcy and Rehabilitation Law). The next part of the article indicates and describes the ways that State support restructuring reforms in agribusiness practice. Banking sector should be also involved in financing of second chance policy, when a debtor is in the position to overcome the financial distress.

\section{MATERIALS AND METHODS}

The aim of this study was to present the changes of bankruptcy proceedings that support agribusiness entities restructuring and survival from economic perspective. This study indicates also the role of the State in the restructuring proceedings creation. The specific objective includes evaluation of the role of the State in the restructuring reforms of indebted farms. This is a conceptual article. The methods include comparative and descriptive analysis.

\section{RESULTS AND DISCUSSION}

Aspects of reorganization proceedings are the focus of an important part of the literature, including LoPucki and Triantis (1994), Eisenberg and Sundgren (1997), Segal (2007). All over the world, from 2009 to 2014, 60 economies implemented 87 reforms on resolving insolvency. Reforms in the area of corporate reorganization were the most common: 10 economies introduced a new reorganization proceeding, and 21 promoted reorganization or made improvements to their existing reorganization framework (World Bank Group, 2016). Along with the Recommendation by the European Commission (2014), Nagham and Boughanmi (2017) have recognized some innovative ways to resolve distress which are good practices found in different countries. These include, e.g. auction approach, debt equity swaps, empowering creditors by expanding their rights under bankruptcy, training, speeding up court procedures, promoting out-of-court workouts and pre-packs, encouraging early filings, and use of the Internet and authenticated professional platforms to sell assets.

This part of the article describes bankruptcy and insolvency law reforms in Poland that strongly supports restructuring procedures. The main advantage is that they give the opportunity for the second chance and business survival increase and allow to take proper restructuring actions in advance and in right course. Poland is one out of seven EU countries (Denmark, Germany, Belgium, Italy, Poland, Greece, Spain) that has been participating in the programme 'Early Warning Europe. Early Warning Poland'. This program helps businesses and the government to build mutual trust, protect companies, job places and the creditors rights. Poland follows the Danish experience, namely 10 years of program existance, 5,000 companies supported, the effective network of pro publico bono mentors. Polish Ministry of Development supports business survival in many ways, especially by second chance policy, new legislation introduction, legal and financial support. This financial aid, namely loan is for regaining financial liquidity of the companies in the period of restructuring plan preparation. Poland receives the financial support from EU sources of PLN 765 million for the period of 2016-2020. The annual budget constitutes approximately 153 million, that includes PLN 53 million for public liabilities restructuring (Ministerstwo Rozwoju, 2017).

New funding provided to a debtor company after the start of insolvency proceedings - known as postcommencement finance -helps businesses in financial distress to recover. Polish insolvency legislation includes two types of proceedings for businesses in financial distress: bankruptcy and restructuring. These two types of procedures that entered into force on 1 January 2016 have different statutes: 1. Bankruptcy 
and Rehabilitation Law, 2. Restructuring Law. The following four restructuring proceedings are available in Poland: 1. Arrangement approval proceedings; 2. Accelerated arrangement proceedings; 3 . Arrangement proceedings; 4. Remedial proceedings.

Table 1 presents all restructuring proceedings that may be entered if the debtor is insolvent within the meaning of the Bankruptcy Law or at risk of insolvency (his economic situation indicates that he may soon become insolvent). A bankruptcy proceeding usually leads to the liquidation of the debtor's assets, but it is also permissible to: approve pre-pack application; and conclude an arrangement between the creditors and the debtor aimed at restructuring of liabilities and maintaining the operation of the debtor's business.

According to Table 1 the important component of restructuring proceedings is an arrangement: the legal act similar to court settlement, containing terms of restructuring. The arrangement is concluded as a result of collecting creditors' votes by the debtor himself, without involvement of the court. The debtor is allowed to manage all of his assets without limitations. Pending execution proceedings concerning a receivable debt covered by the accelerated arrangement and arrangement are suspended by operation of

Table 1. Comparison of changes of Polish bankruptcy and insolvency proceedings

\begin{tabular}{|c|c|c|c|c|c|}
\hline \multirow{2}{*}{ Specification } & \multirow{2}{*}{$\begin{array}{c}\begin{array}{c}\text { Bankruptcy and } \\
\text { Rehabilitation Law }\end{array} \\
\begin{array}{c}\text { Bankruptcy } \\
\text { proceedings }\end{array}\end{array}$} & \multicolumn{4}{|c|}{ The new act on Restructuring Law proceedings } \\
\hline & & $\begin{array}{c}\text { Arrangement } \\
\text { approval }\end{array}$ & $\begin{array}{l}\text { Accelerated } \\
\text { arrangement }\end{array}$ & Arrangement & Remedial \\
\hline $\begin{array}{c}\text { Initiation of the } \\
\text { procedure }\end{array}$ & $\begin{array}{l}\text { Debtor or by any } \\
\text { debtor's personal } \\
\text { creditor. }\end{array}$ & $\begin{array}{l}\text { Only the debtor } \\
\text { by entering } \\
\text { into a contract } \\
\text { with a licensed } \\
\text { restructuring } \\
\text { counsellor chosen } \\
\text { by the debtor. }\end{array}$ & $\begin{array}{l}\text { Only the debtor } \\
\text { by filling an } \\
\text { application to the } \\
\text { court. }\end{array}$ & $\begin{array}{l}\text { Only the debtor } \\
\text { by filling an } \\
\text { application to the } \\
\text { court. }\end{array}$ & $\begin{array}{l}\text { Personal creditor } \\
\text { of the debtor or by } \\
\text { the debtor himself. }\end{array}$ \\
\hline Purposes & $\begin{array}{l}\text { Main aim is to } \\
\text { satisfy the claims } \\
\text { of the creditors } \\
\text { and, if possible, } \\
\text { for the existing } \\
\text { business of the } \\
\text { debtor to continue } \\
\text { operating on the } \\
\text { market. }\end{array}$ & $\begin{array}{l}\text { The debtor } \\
\text { is entitled to } \\
\text { negotiate the terms } \\
\text { of the arrangement } \\
\text { without the court } \\
\text { involvement. }\end{array}$ & $\begin{array}{c}\text { Restructuring } \\
\text { proceedings } \\
\text { combined with a } \\
\text { court supervision. }\end{array}$ & $\begin{array}{c}\text { Restructuring } \\
\text { proceedings } \\
\text { combined with a } \\
\text { court supervision. }\end{array}$ & $\begin{array}{l}\text { Entered when } \\
\text { ordinary } \\
\text { proceedings are } \\
\text { not effective. }\end{array}$ \\
\hline $\begin{array}{l}\text { Outcomes from } \\
\text { the proceedings }\end{array}$ & $\begin{array}{l}\text { Bankruptcy may } \\
\text { be declared in case } \\
\text { of a debtor who } \\
\text { becomes insolvent. }\end{array}$ & $\begin{array}{l}\text { The total disputed } \\
\text { claims that give } \\
\text { the right to vote } \\
\text { on arrangement } \\
\text { has not exceed } \\
15 \% \text { of the total } \\
\text { claims giving the } \\
\text { right to vote on the } \\
\text { arrangement. }\end{array}$ & $\begin{array}{l}\text { The total disputed } \\
\text { claims that give } \\
\text { the right to vote } \\
\text { on arrangement } \\
\text { has not exceed } \\
15 \% \text { of the total } \\
\text { claims giving the } \\
\text { right to vote on the } \\
\text { arrangement. }\end{array}$ & $\begin{array}{l}\text { The total disputed } \\
\text { claims that give } \\
\text { the right to vote on } \\
\text { arrangement has } \\
\text { exceed } 15 \% \text { of the } \\
\text { total claims giving } \\
\text { the right to vote on } \\
\text { the arrangement. }\end{array}$ & $\begin{array}{l}\text { The debtor has to } \\
\text { cover the cost of } \\
\text { the proceedings } \\
\text { and the liabilities } \\
\text { arising after its } \\
\text { opening. }\end{array}$ \\
\hline
\end{tabular}

Source: own study based on Deloitte. Legal (2017). 
law on the day when the proceedings are opened. The arrangement is reached on the meeting of creditors convened by the judge-commissioner. The arrangement proceedings require greater involvement of the court supervision than accelerated arrangement. In case of arrangement the debtor has to cover the cost of the proceedings and the liabilities arising after its opening. On the contrary remedial procedure the debtor has to cover the cost of the proceedings and the liabilities arising after its opening. Accelerated arrangement allows the debtor to manage his assets, but he cannot perform activities which fall beyond the scope of ordinary business activities. Such activities require consent of the court supervisor. The same above conditions refer to the arrangement proceeding. After the opening of the remedial proceedings the debtor loses the authority to manage his assets (as a rule) and the court appoints the receiver, who is authorized to manage the debtor's assets. In case of the remedial procedure the debtor can manage his assets only in special circumstances and only under the court's permit.

This part of the article presents the restructuring possibilities of indebted farms. According to banks that cooperate with ARMA 1690 producers have problems with loans repayment (PLN 158.64 million). The draft act on restructuring the debt of agricultural farms includes the rules and conditions for the restructuring of farmers' debts. The condition for using the assistance is to conduct agricultural activity at least three years before the loss of ability to service debt. The farmers who are insolvent or at risk of insolvency in the meaning of the Act of 15 May 2015 Restructuring Law can apply for this support.

The project provides four forms of assistance:

- granting by ARMA subsidies for interest on restructuring loans that support repayment of debt;

- ARMA granting loans for repayment of debt;

- granting by KOWR a guarantee for the repayment of restructuring loans;

- takeover of debt by KOWR.

This new law proposal is a special form of state aid that will be granted to entities that are in financial distress without ability to regain financial liquidity that refers to market conditions.

\section{CONCLUSIONS}

The Restructuring Law provides important, largescale changes to the Polish insolvency regime. As a result, a new approach to agribusiness failure and insolvency that aims to shift the focus of insolvency proceedings from liquidation to pre-insolvency restructuring, enables viable companies to return to going concern status. Restructuring proceedings are intended to provide an opportunity for a debtor to avoid declaration of bankruptcy through enabling him to start restructuring. The implementation (contents) part of the restructuring plan contains provisions on how the legal positions of the bankruptcy debtor and other participants in the proceedings will be affected by the execution of the plan.

In order to increase the efficiency of restructuring procedures the following conditions are needed: possibility to file early with the objective of avoiding insolvency, legal position of the creditor/s and debtor with the objective of maintaining his business activities, possibility of a stay on individual enforcement actions, adoption of the restructuring plans by creditors, protection for new finance granted in restructuring procedures.

Restructuring proceedings support the permission for the debtors to retain control of the business and provide lenders with various protections to implement new financing to assist the restructuring plan and allow second chance for entrepreneurs.

\section{REFERENCES}

1. Amankwah-Amoah, J. (2016). An Integrative Process Model of Organisational Failure. Journal of Business Research, 69 (9), pp. 3388-3397.

2. Boratyńska, K. (2016). FsQCA in Corporate Bankruptcy Research. An Innovative Approach in Food Industry. Journal of Business Research, 69 (11), pp. 5529-5533.

3. Deloitte. Legal (2017). A Guide to Pre-insolvency and Insolvency Proceedings Across Europe. Retrieved from: https:/www2.deloitte.com/content/dam/Deloitte/global/Documents/Legal/dttl-legal-deloitte-europe-insolvency-proceedings-guide.pdf [Accessed 20.05.2018].

4. Eisenberg, T., Sundgren, S. (1997). Is Chapter 11 Too Favorable to Debtors? Evidence from Abroad. Cornell Law Review, 82 (6), pp. 1532-1567. 
5. European Commission (2014). Commission Recommendation of 12 March 2014 on a new approach to business failure and insolvency. 2014/135/EU. OJ L 74 of 14.03.2014.

6. Evans, J., Borders, A.L. (2014). Strategically Surviving Bankruptcy During a Global Financial Crisis: The Importance of Understanding Chapter 15. Journal of Business Research, 67 (1), pp. 2738-2742.

7. Franc-Dąbrowska, J., Porada-Rochoń, M., Suwała, R. (2016). Enterprise Insolvency and the Effects on the Local and Regional Community - the Social Economy Perspective. Acta Scientiarum Polonorum. Oeconomia, 15 (2), pp. 37-47. Retrieved from: http://acta_oeconomia.sggw.pl/wp-content/uploads/Acta_Oeconomia 15_2_2016.pdf [Accessed 15.04.2018].

8. LoPucki, L., Triantis, G.G. (1994). A Systems Approach to Comparing U.S. and Canadian Reorganization of Financially Distressed Companies. Harvard International Law Review, 35, pp. 267-343.

9. Ministerstwo Rozwoju (2017). Informacje z konferencji zorganizowanej $\mathrm{w}$ dniu 21.06.2017 r. przez Ministerstwo Rozwoju, Instytut Allerhanda oraz Stowarzyszenie Praktyków Restrukturyzacji pt. „Prawo restrukturyzacyjne jako element Polityki Nowej Szansy - szanse i problemy finansowania przedsiębiorstw w restrukturyzacji" [Information of the conference organised by Ministry of Development on June 21, 2017, Allerhand Institute and Restructuring Practitioners Association entitled 'Restructucturing law as a part of New Opportunity Policy - opportunities and problems of financing enterprises that are in restructuring'].

10. Nagham, N., Boughanmi, A. (2017). Can Innovative Reforms and Practices Efficiently Resolve Financial distress? Journal of Cleaner Production, 140, pp. 1860 -1871 .

11. Segal, N. (2007). The Effect of Reorganization Proceedings on Security Interests: The Position under English and U.S. Law. Brooklyn Journal of International Law, 32 (3), pp. 927-982.

12. Ustawa $z$ dnia 15 maja 2015 r. Prawo restrukturyzacyjne [Act of 15 May 2015 Restructuring Law]. Journal of Laws 2015, item 978.

13. Ustawa $z$ dnia 28 lutego 2003 r. Prawo upadłościowe i naprawcze [Act of 28 February 2003 Bankruptcy and Rehabilitation Law]. Journal of Laws 2003, item 535.

14. World Bank Group (2016). Doing Business 2016. Retrieved from: http://www.doingbusiness.org/ /media/ WBG/DoingBusiness/Documents/Annual-Reports/ English/DB16-Full-Report.pdf [Accessed 10.05.2018]. 